Trends in Immunotherapy (2020) Volume 4 Issue 2

doi:10.24294/ti.v4.i2.1064

\title{
CAR-T Therapy for Solid Tumors: Development of New Strategies
}

\author{
Marvin de los Santos ${ }^{1}$, Samuel D. Bernal ${ }^{1,2^{*}}$ \\ ${ }^{1}$ GlobeTekPro, Los Angeles, California 91367, USA, Globetek Science Foundation, Manila, 1227, Philippines, \\ midelossantos1215@gmail.com \\ ${ }^{2}$ Cedars-Sinai Medical Center, Section of Hematology \& Oncology, 8700 Beverly Blvd, Los Angeles, California 90048, \\ USA, sberne@ucla.edu (to whom correspondence should be sent).
}

\section{ABSTRACT}

The recent approval of two CAR-T therapies by US Food and Drug Administration (FDA) marks a very significant development in cell-based cancer immunotherapy. This milestone was demonstrated by the effectiveness of eradicating hematologic cancers using CD19-specific CARs. The success spurred development of immune cell therapies for other cancers, especially solid tumors. The generation of novel CAR constructs for these cancer types represents a major challenge in bringing the technology 'from-bench-to-bedside'.In this review, we outline some new technologies we have developed to equip CAR-T cells to enhance efficiency while decreasing toxicity of CAR-T therapies in solid tumors.

Keywords: Cancer Immunotherapy; Chimeric Antigen Receptor T cell Therapy; Lymphoma; Solid Tumors; Cancer Molecular Profiling

\section{Introduction}

In the past, surgery, radiation and chemotherapy were at the forefront of recommended and accepted treatments for different cancer types. However, the efficacy of these therapies were limited due to $(a)$ high recurrence rate ${ }^{[1,2,3]},(b)$ hard-to-detect residual metasta$\operatorname{sis}^{[4,5]},(c)$ frequent late stage diagnosis ${ }^{[6,7]},(d)$ elevated refractory cases from resistant cancers ${ }^{[8,9]}$ and $(e)$ invasiveness and toxicity to patients. In response to addressing these drawbacks, a new method entered the treatment group - immunotherapy. This kind of therapy utilizes the body's immune function to detect cancer antigens and to mount an attack against cancer cells. Due to the remarkable positive clinical outcome brought by immunotherapy, it is now becoming as the first line of treatment in some cancer types ${ }^{[10]}$. The technology involves transfusions with (autologous or allogeneic) $\mathrm{T}$ cells that are engineered to recognize cancer cells (Figure 1a), known as chimeric antigen receptor $\mathrm{T}$ (CAR-T) cell therapy ${ }^{[11,12]}$.
CAR-Ts are engineered $\mathrm{T}$ cells expressing $\mathrm{scFv}$ (single chain variable fragment) domain of antigen-specific antibody linked to a TCR (T cell receptor)-associated intracellular signaling domain such as CD3 zeta ${ }^{[13]}$ (Figure 1b). The scFv redirects CAR-T cells to recognize cancer cells in an HLA (human leukocyte antigen)-independent manner and the TCR intracellular domain induces T-cell dependent cancer killing ${ }^{[14,15]}$. After the remarkable demonstration of efficiency by the first engineered $\mathrm{T}$ cells pioneered by Eshhar and coworkers $^{[16]}$, variability in $\mathrm{T}$ cell functionalities have emerged. The $1^{\text {st }}$ generation CAR expresses the CD3 zeta domain alone ${ }^{[17]}$ while the $2^{\text {nd }}$ generation is made by tandem with $\mathrm{CD} 28^{[18]}$ and the 3rd generation has an added domain from either CD137, CD134, ICOS or $\mathrm{CD} 27^{[19-22]}$. The emerging 4th generation has an added inducible IL2 or IL12 cytokine secretion ${ }^{[23]}$ for more potent immune activity (Figure 1c).

Copyright (C) 2020 Marvin de los Santos et al.

doi: 10.24294/ti.v4.i2.1064

EnPress Publisher LLC.This work is licensed under the Creative Commons Attribution-NonCommercial 4.0 International License (CC BY-NC 4.0). http://creativecommons.org/licenses/ by/4.0/ 


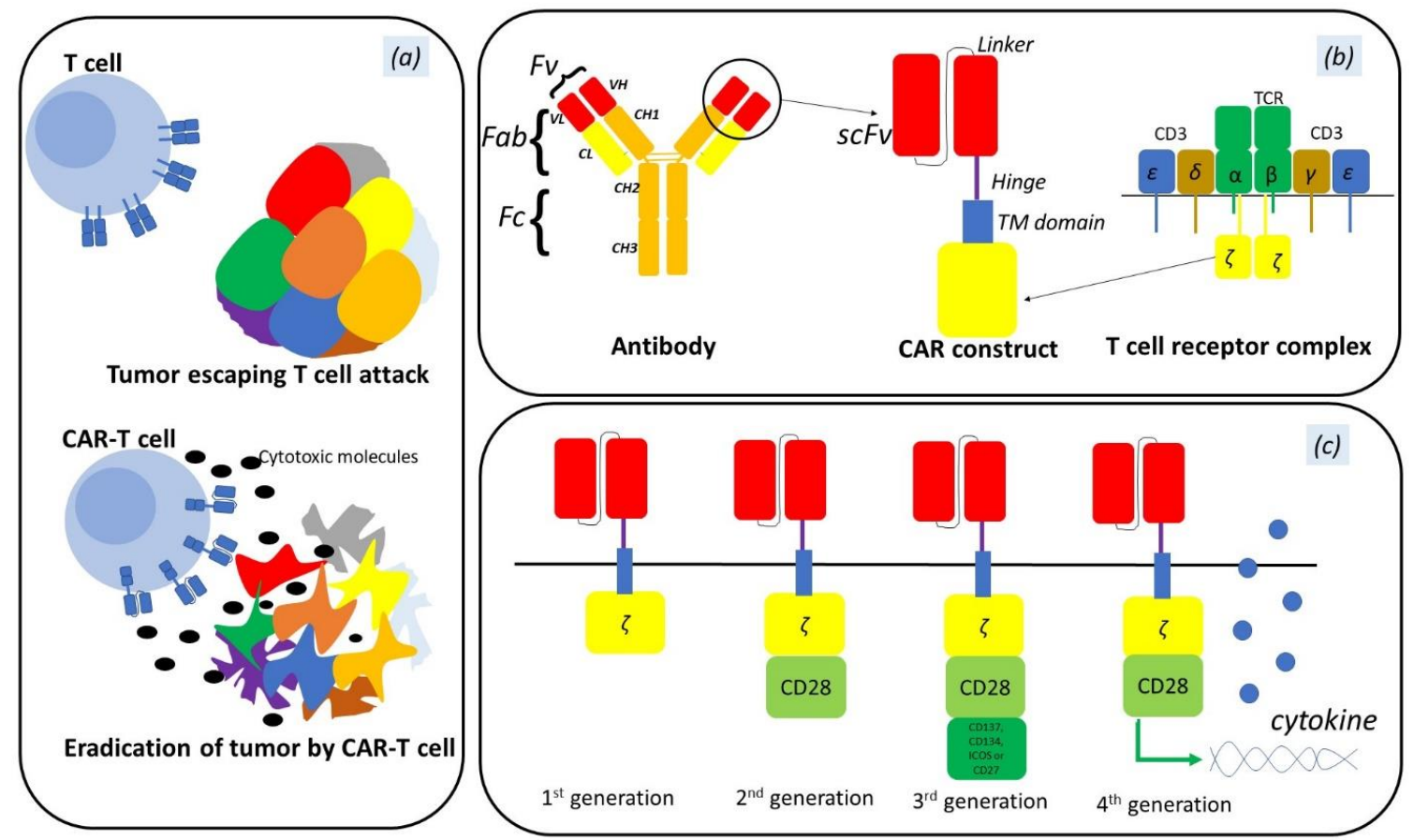

Figure 1; Schematic representation of chimeric antigen receptor (CAR) T cell therapy against cancer. Engineered T cells harboring CARs are more efficient in eradicating cancer cells compared to their un-engineered counterparts (a). This enhance anti-cancer activity is made possible by expression of an extracellular CAR domain with tumor associated antigen (TAA)-binding moiety, usually a single chain variable fragment $(\mathrm{scFv})$ which was cloned from antibody gene with specificity to the desired TAA. A hinge (or spacer) region is placed after the scFv for flexibility followed by a transmembrane (TM) domain and one or more signaling domains involved in T cell activation (b). Functionality of CARs were enhanced by modifying the number and type of intracellular signaling domains of CAR. The first-generation CAR is equipped with the stimulatory domain of the T cell receptor complex zeta ( $\zeta$ ) chain. The second-generation CAR has the addition of CD28 co-stimulatory domain to ensure full activation of T cell response. The third-generation CAR is generated by adding a third co-stimulatory domain (CD137, CD134, ICOS or CD27) in tandem with CD28/zeta chain to potentiate maximally the immune response against cancer. The lastly, the fourth-generation CAR includes an inducible cytokine such as IL2 or IL12 to deliver enhanced anti-tumor effect and prevent down-modulation of CAR-T cytotoxic activity (c).

Over the past two decades since the description of first CAR-T trials, there have been more than 200 CAR-T cell therapies being evaluated in clinical trials globally (based on database search in Clinicaltrials.gov); and yet, there were only two CAR-T cell therapies approved by US FDA (Food and Drug Administration) for treatment of hematologic cancers ${ }^{[24]}$. With these approvin clinical studies. Several of these CAR-T constructs are directed to solid tumors (Table 1). In recent years, the developments in molecular genetics, molecular immunology and precision medicine directed to solid tumors have opened exciting opportunities for engineering immune cells directed to the many different human solid tumors and for customizing treatments based on the moals, more CAR-Ts are projected to emerge for evaluation

\begin{tabular}{|l|l|l|l|l|}
\hline Target Antigen & Cancer Type & $\begin{array}{l}\text { Initial } \\
\text { Posting }\end{array}$ & Strategy & References \\
\hline $\begin{array}{l}\text { EGFR (Epidermal } \\
\text { Growth Factor Re- } \\
\text { ceptor) }\end{array}$ & $\begin{array}{l}\text { Lung cancer and other EGFR+ } \\
\text { solid tumors }\end{array}$ & Jun-13 & EGFR-specific & NCT01869166 \\
\hline & Advanced solid tumor & Jun-17 & $\begin{array}{l}\text { CTLA-4 and PD1 } \\
\text { antibodies expressing }\end{array}$ & NCT03182816 \\
\hline
\end{tabular}




\begin{tabular}{|c|c|c|c|c|}
\hline & & & CAR-T cells & \\
\hline & Colorectal cancer & May-18 & IL-12 inducible & NCT03542799 \\
\hline \multirow[t]{2}{*}{ EGFRvIII } & Malignant glioblastoma & Oct-11 & EGFRvIII-specific & NCT01454596 \\
\hline & Residual glioblastoma & Aug-14 & EGFRvIII-specific & NCT02209376 \\
\hline \multirow[t]{2}{*}{ MUC1 } & $\begin{array}{l}\text { Malignant glioblastoma, colorectal } \\
\text { and gastric cancers }\end{array}$ & Nov-15 & MUC1-specific & NCT02617134 \\
\hline & Advanced solid tumor & Jun-17 & $\begin{array}{l}\text { CTLA-4 and PD1 } \\
\text { antibodies expressing } \\
\text { CAR-T cells }\end{array}$ & NCT03179007 \\
\hline \multirow[t]{2}{*}{ IL13R $\alpha 2$} & Malignant glioblastoma & Aug-14 & IL13R $\alpha 2$-specific & NCT02208362 \\
\hline & Brain tumors & Aug-08 & $\begin{array}{ll}\text { Containing } \mathrm{Hy} / \mathrm{TK} \\
\text { suicide gene }\end{array}$ & NCT00730613 \\
\hline \multirow[t]{2}{*}{ Mesothelin } & $\begin{array}{l}\text { Cervical cancer and other meso- } \\
\text { thelin-positive solid cancers }\end{array}$ & Apr-12 & Mesothelin-specific & NCT01583686 \\
\hline & Solid tumors & Jan-17 & $\begin{array}{l}\text { PD-1 antibody ex- } \\
\text { pressing }\end{array}$ & NCT03030001 \\
\hline $\mathrm{CD} 70$ & $\begin{array}{l}\text { Pancreatic and other } \\
\text { CD70-expressing tumors }\end{array}$ & Jul-17 & CD70-specific & NCT02830724 \\
\hline CD171 & $\begin{array}{l}\text { Neuroblastoma and ganglioneuro- } \\
\text { blastoma }\end{array}$ & Dec-14 & CD171-specific & NCT02311621 \\
\hline \multirow[t]{2}{*}{$\begin{array}{l}\text { CEA (carcinembry- } \\
\text { onic antigen) }\end{array}$} & $\begin{array}{l}\text { Lung, colorectal, gastric, breast } \\
\text { and pancreatic }\end{array}$ & Jan-15 & CEA-specific & NCT02349724 \\
\hline & Liver metastasis & Aug-16 & $\begin{array}{l}\text { Regional delivery of } \\
\text { CAR-T cells }\end{array}$ & NCT02850536 \\
\hline \multirow[t]{2}{*}{ ЕрСАM } & $\begin{array}{l}\text { Nasopharyngeal carcinoma } \\
\text { and breast cancer }\end{array}$ & Sep-16 & EpCAM-specific & NCT02915445 \\
\hline & $\begin{array}{l}\text { Colon, esophageal, pancreatic, } \\
\text { prostate, gastric and hepatic cancer }\end{array}$ & Jan-17 & EpCAM-specific & NCT03013712 \\
\hline \multirow[t]{2}{*}{ Her2 } & Her-2 positive solid tumors & Sep-13 & Her2-specific & NCT01935843 \\
\hline & Central nervous system tumor & Apr-18 & Tumoral delivery & NCT03500991 \\
\hline $\begin{array}{l}\text { FAP (fibroblast acti- } \\
\text { vation protein) }\end{array}$ & Malignant Pleural Mesothelioma & Nov-12 & FAP-specific & NCT01722149 \\
\hline EphA2 & Malignant glioma & Oct-15 & EphA2-specific & NCT02575261 \\
\hline \multirow[t]{5}{*}{ GD2 } & $\begin{array}{l}\text { Sarcoma, osteosarcoma, neuro- } \\
\text { blastoma and melanoma }\end{array}$ & Apr-14 & caspase-9 inducible & NCT02107963 \\
\hline & Sarcomas & Oct-13 & $\begin{array}{l}\text { caspase-9 inducible } \\
\text { and VZV vaccine } \\
\text { activation }\end{array}$ & NCT01953900 \\
\hline & Solid tumors & Dec-16 & $\begin{array}{l}\text { caspase-9 and cyto- } \\
\text { kine inducible }\end{array}$ & NCT02992210 \\
\hline & Neuroblastoma & Apr-13 & caspase-9 inducible & NCT01822652 \\
\hline & Cervical cancer & Nov-17 & Multi-antigen target- & NCT03356795 \\
\hline
\end{tabular}




\begin{tabular}{|l|l|l|l|l|}
\hline & & & ing & \\
\hline & Glioma & Aug-17 & GD2-specific & NCT03252171 \\
\hline CD133 & $\begin{array}{l}\text { Liver cancer and other CD131 } \\
\text { positive tumors }\end{array}$ & Sep-15 & CD133-specific & NCT02541370 \\
\hline GPC3 & Hepatocellular carcinoma & Mar-16 & GPC3-specific & NCT02723942 \\
\hline & $\begin{array}{l}\text { Hepatocellular carcinoma and } \\
\text { squamous lung carcinoma }\end{array}$ & Jun-17 & GPC3-specific & NCT03198546 \\
\hline Mepatocellular carcinoma & May-17 & GPC3-specific & NCT03146234 \\
\hline PSCA & Liver metastases & Aug-16 & MG7-specific & NCT02862704 \\
\hline ErbB & Pancreatic cancer & Apr-16 & PSCA-specific & NCT02744287 \\
\hline
\end{tabular}

Table 1. Target tumor-associated antigens in solid cancers, clinical trial duration and type of CAR-T strategy (Data from Clinicaltrials.gov).

\section{Discussion}

\subsection{Challenges in CAR-T Therapy for solid tumors and how to overcome them:}

The success of CD19-targetted CAR-T cells against hematological cancers is aided by the ability to recognize and bind to cancer cells readily upon CAR-T infu$\operatorname{sion}^{[18,12]}$. In solid cancers, particularly in bulky tumors, there are multiple factors that complicate efficient targeting of cancer cells, including penetrability of the tumor and specificity of $\mathrm{scFv}$ to antigens present in the cancer but not, or much less, in normal cells ${ }^{[25]}$. Several potential targets in solid tumors have been identified and some of them are being evaluated for clinical efficiency (Table 1$)^{[26,27]}$. Numerous factors contribute to the complexity in targeting solid tumors, including mechanisms that hinder access of these CAR-T cells to the site of tumor, cell trafficking, homing and extravasation, tumor infiltration, circumventing the tumor microenvironment, CAR affinity, CAR-T toxicity and other characteristics of cancer cells such as tumor heterogeneity, genomic instability, immune-checkpoint regulation and target down regulation (Figure 2)

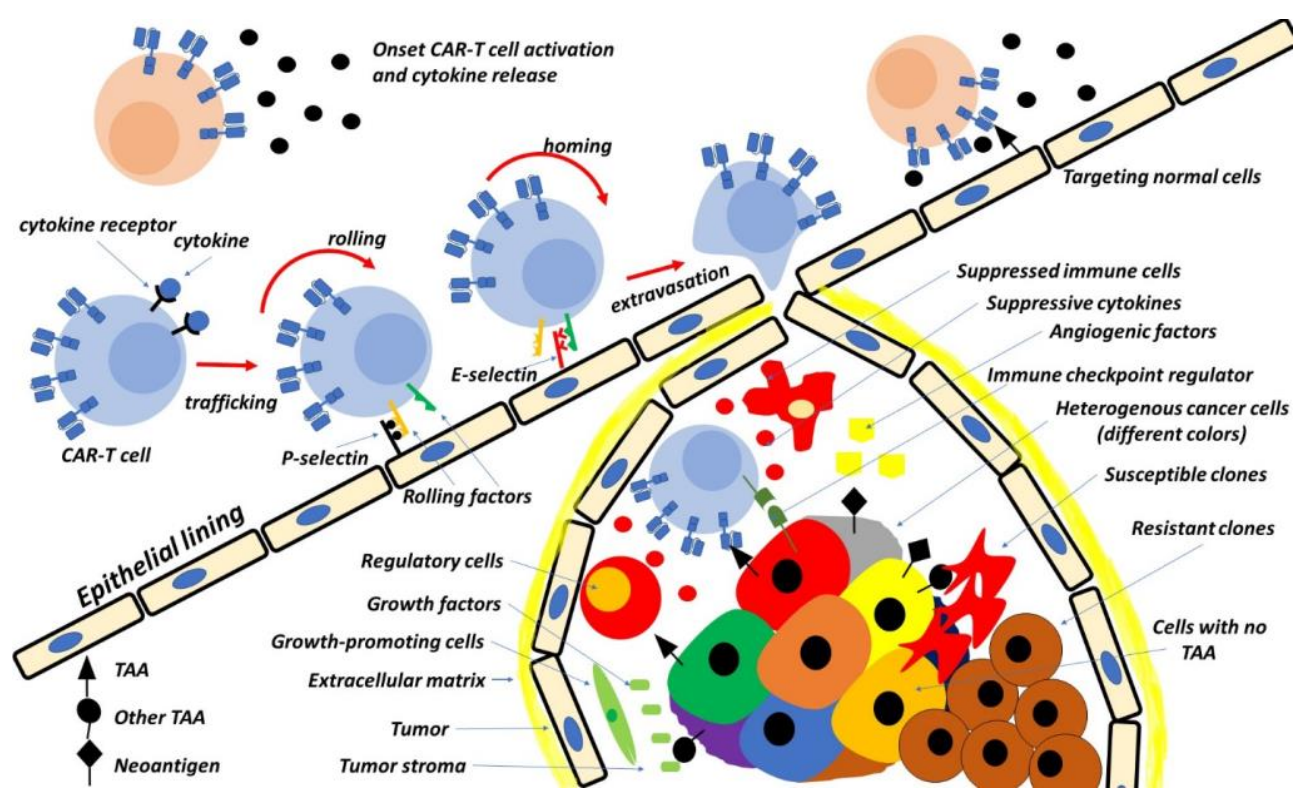

Figure 2; Challenges and point-of-improvements in CAR-T for solid tumors. This schematic representation shows the major hindrances encountered by CAR-Ts in delivering cytotoxic effect against solid cancers. These hindrances limit the efficiency of CAR-T therapy which could be focus for potential improvement. 


\subsection{Enhancing CAR-T cell efficiency:}

A. CAR-T cell trafficking. Inefficient migration at the tumor site essentially limits the efficiency of CAR-T therapy against tumor cells ${ }^{[26]}$. This restrictive impact might be due to chemokine mismatch released by cancer cells with the chemokine receptors expressed by CAR-T cells $^{[28,29]}$. Previous study demonstrated that activated $\mathrm{CD}^{+} \mathrm{CXCR}^{\text {high }}{ }^{\text {tumor-infiltrating lymphocytes render }}$ inefficient for recruitment due to lack of receptor expression for related chemokine ligands such as CXCL9 and CXCL10 produced by cancer cells ${ }^{[30]}$. In other reports, arming CAR-T cells with receptors for cancer-specific chemokines such as CCR2B (CCL2 receptor) ${ }^{[31]}$, CXCR2 (CXCL1 receptor) ${ }^{[32], ~ C C R 4 ~(C C L 17 ~ r e c e p-~}$ tor ${ }^{[33]}$ and modifying the expression of immune activation pathway molecules such as protein kinase $\mathrm{A}^{[34]}$ to increase baseline expression of chemokine receptor improved trafficking and cancer eradication.

The workflow of re-engineering $\mathrm{T}$ cells for added receptor is customarily difficult as cancers from different patients produce different chemokine profiles. In an attempt to circumvent this, local instillation approach has emerged in clinical trials. This site-specific CAR-T administration bypasses the drawbacks of inefficient trafficking; however, this may not prove to be beneficial for those with multiple and residual metastasis or tumors that are concealed within multiple organs of the body. Hence, technical administration is somehow challenging. Nonetheless, preclinical results of regional and intratumoral delivery of CAR-T cells provide promising results against glioblastoma ${ }^{[35]}$, liver cancer ${ }^{[36]}$, and in some types of head and neck cancers ${ }^{[37]}$.

Another effort to increase CAR-T trafficking emerged from the use of oncolytic vaccinia virus strain $^{[38]}$. While some CAR-Ts are engineered to harbor receptors for chemokines, these oncolytic viruses can serve as tumor-specific delivery of chemokine genes so cancer cells release matching chemokines that are efficiently recognized by CAR-T cells; thus, enhancing recruitment of tumor infiltrating effector T cells. Preclinical reports on oncolytic virus-mediated transgenic delivery of CXCL-11 ${ }^{[39]}, \mathrm{CCL}-5^{[40]}, \mathrm{CCL}-19^{[41]}$ resulted in elevated expression of granzyme B and INF-y in tumor site with enhanced tumor mass reduction.
B. Homing and extravasation of CAR-T cells to tumor site. The interaction of chemokine receptors with their ligands induces expression of $\mathrm{T}$ cell rolling-associated proteins [E- and P- selectin ligands ${ }^{[42,43]}$ including related homing and adhesion molecules in $\mathrm{T}$ cells such as LFA-1 and VLA-4 integrins to track the gradient of chemokines released through the blood stream $^{[44]}$. However, the efficiency of extravasation and homing into the tumor site remained challenging. Escape from neo-vessel epithelium by extracellular-matrix (ECM) degradation hinders CAR-T cells from reaching the target site ${ }^{[45]}$. Histopathological features of solid tumors display high concentration of blood vessels and the extracellular lining of epithelium is composed of protective barriers that need to break down. In vitro and mouse model studies on transduction of heparanase (HPSE) gene in CAR-T cells enhanced heparan sulfate proteoglycan degradation in the ECM resulting in more efficient targeting of neuroblastoma cancer cells ${ }^{[46]}$. Other ECM-targeted approach such as anti-fibulin 3 CAR-T cells was found to efficiently eradicate glioblastoma cells in mouse models evidenced by increased expression of IFN-gamma, IL-2, perforin and granzymes in the site of tumor $^{[47]}$. While some are targeting ECM-components, some CAR-Ts are modified to target VEGFR (vascular endothelial growth factor receptor) ${ }^{[48]}$ to specifically direct T-cell effect as guide from tumoral activities that hijacks vasculature formation.

Advances in oncolytic virus strategy have pronounced other modes of assisting CAR-T cell extravasation. Some studies demonstrated the enhancement of CAR-T cell infiltration following administration of oncolytic viruses that express different ECM-degrading enzymes such as collagenase ${ }^{[49]}$, hyaluronidase ${ }^{[50]}$ and matrix metalloproteinase 9 (MMP-9) ${ }^{[51]}$. Other modes of oncolytic virus-assisted CAR-T extravasation includes the arming of these viruses with anti-VEGF ${ }^{[2,53]}$ or anti-VEGFR ${ }^{[54]}$ or other inhibitors of these molecules to inhibit vasculature growth.

Cancer cells also secrete angiogenic factors such as Ang-1 or angiopoietin ${ }^{[55,56]}$ that downregulates expression of T-cell adhesion factors ligands such as ICAM-1, VCAM-1 and other T-cell rolling molecules such as E-selectins. Theoretically, blocking or targeting these angiogenic factors and upregulation of these adhesion 
molecules and $\mathrm{T}$ cell rolling factors may result in enhanced trafficking of CAR-T cells into tumor site.

\section{CAR-T cells infiltrating the tumor microen-} vironment (TME). Physically, the extracellular-matrix (ECM) serves as scaffold for all cells in the tumor microenvironment (TME). However, attacking the ECM itself is not a guarantee to successfully kill cancer cells. While ECM serves as barrier, the TME provides another level of comfort for cancer cells to evade immune destruction by CAR-T cells ${ }^{[57]}$. As a cancer-made habitat, TME is dominated by tumor-induced interactions favoring cancer growth and suppressing immune functions including promoting metastasis, nurturing mutational accumulation, resisting apoptotic signals and concentrating proliferative factors. All these events are orchestrated by the ability of cancer cells to turn all other related cells as traitors to the body's natural processes. Key players in building TME involves an interplay of different cells and complex factors.

$i$. Tumor growth-inducing cells. Myofibroblasts or fibroblastic cells are specialized cells that develop in response to injury ${ }^{[58]}$. In TME, myofibroblasts are called CAFs (cancer associated fibroblasts). These cells play a very significant role in promoting tumor growth as they secrete growth factors such as insulin-like growth factor 1 (IGF-1) and fibroblast growth factor (FGF) ${ }^{[59]}$. CAFs also secrete anti-inflammatory cytokines such as TGF-B (transforming growth factor beta) ${ }^{[60]}$ which suppresses immune attack while contributing to metastatic potentials of cancer cells. Chemokine CXCL12 derived from fibroblast of TME can serve as chemoattractant for recruitment of other TME-associated cells ${ }^{[61]}$ which will be discussed below. Other key factors in tumorigenesis is the added support provided to tumor vasculature and blood vessel formation by other cellular components such as stromal endothelial cells ${ }^{[62]}$, vascular endothelial cells ${ }^{[63]}$, and pericytes ${ }^{[64]}$ which are all known to create dynamic interplay in providing the overall TME region a suitable habitat for cancer growth.

Recent advancement in CAR-T therapy found that CARs directed against fibroblast activation protein (FAP) have better anti-tumor effects ${ }^{[65]}$. Other CARs as previously described above targeting receptors for growth factors such as VEGFR can circumvent this active involvement of CAFs and other tumor growth-inducing cells in tumorigenesis. It is projected that the combinatorial use of ECM degrading and TME-associated stromal cells such as HSPE and FAP-targeted CARs may efficiently increase the chance of CAR-T cells to reach the site of tumor.

ii. Immune cells and associated immune-suppressing cells. Surprisingly, the body's immune cells reside within TME, but their functions have been deactivated and altered. A subclass of $\mathrm{T}$ cell population, $\mathrm{CD} 4{ }^{+} \mathrm{Foxp}^{+} \mathrm{CD} 25^{+}$regulatory $\mathrm{T}$ cells (Tregs), and $\mathrm{B}$ cell subclass, $\mathrm{CD} 5^{+} \mathrm{CD} 1 \mathrm{~d}^{\text {high }}$ regulatory B cells (Breg or B10) are concentrated within the tumor site ${ }^{[66,67]}$ which secrete IL-10, TGF-B (transforming growth factor beta) and activates immune-checkpoint receptors in most pro-inflammatory $\mathrm{T}$ cell population leading to their deactivation. Other groups of immune cells found in TME are natural killer (NK) and natural killer T (NKT) cells while their functions in tumor stroma are unknown, a number of studies demonstrated their anergic phenotype and might have the potential to secrete anti-inflammatory cytokines $^{[68]}$. Phagocytes such as dendritic cells (DCs) and macrophages are also associated with TME. With their ability to engulf and present antigens via HLA pathway, these two types of immune cells are supposed to cascade immunologic events leading to cancer eradication. However, DCs are found to have defective antigen processing and presentation of tumor-associated antigens (TAAs) due to strong immunosuppressive effects of anti-inflammatory cytokines secreted by other cells of $\mathrm{TME}^{[69]}$. Macrophages on the other hand are discovered to have converted from cancer-killing (M1) to cancer-promoting phenotype (M2) or also called tumor-associated macrophages (TAM) ${ }^{[70]}$. M2 cells residing in TME converts from producing IL-12 cytokines, which is essential for activating immune function, in to IL-10 which favors immune suppression. In fact, clinical data suggest that high TAM correlates to poor cancer $\operatorname{prognosis}^{[71]}$.

Several other key players of TEM such as myeloid-derived suppressor cells deactivate CD8+ T cells and cooperatively converts M1 to TAM phenotype ${ }^{[72]}$. Tumor-associated neutrophils (TAN) are found to enhance angiogenesis and cancer metastasis ${ }^{[73]}$. Adipocytes $^{[74]}$ and neuroendocrine cells ${ }^{[75]}$ produce and stimulate hormone-like factors that induce hormone-depended 
cell growth and downregulate immune response along with anti-inflammatory cytokines released by themselves and all other cells.

With the continuous development of CARs, the $4^{\text {th }}$ generation CAR-T cells (also called TRUCK) can be equipped with inducible pro-inflammatory cytokine such as IL-2, IL-18 and IL-12 to circumvent the saturation of anti-inflammatory cytokines present in tumor stroma. Recent report showed superior antitumor activity of $4^{\text {th }}$ generation CAR-T cells where T-bet expression have increased in $\mathrm{T}$ cell population accompanied with reduction of TAMs and Tregs in tumor site with promising clinical correlation of increased conversion to CD8+ and CD4+ subtypes ${ }^{[23]}$. The induction of immune-activating cytokines can also elicit NK and NKT cells activation in solid tumors leading to more efficient cancer eradication. Consecutively, administration of oncolytic virus which is armed to express inflammatory cytokines following CAR-T administration can theoretically circumvent the immunosuppressive nature of TME.

iii. Non-cellular components of TME. The creation of sub-habitual location of tumor inside the body creates a condition where some of the normal cellular functions are impossible to carry out. Generally, TME and the tumor itself is packed with rapidly dividing cells where oxygen (hypoxia) and nutrients are usually limiting, leading to an environment that is more acidic and lower in glucose concentration ${ }^{(76]}$. This acidic environment and lack of nutrients in tumor stroma generate a stress response leading to $\mathrm{T}$ cell anergy or apoptosis or conversion into Treg alongside with immune suppressing activities of anti-inflammatory cytokines ${ }^{[77]}$. Hypoxia was found to have big impact in tumor initiation and progression by activating hypoxia inducible factor (HIF) ${ }^{[78]}$ which target and transcribe multiple genes associated with survival of cells and also cooperatively induces pro-inflammatory environment that initially recruits immune cells in TME and are coaxed to become traitors of immune activity by releasing cytokines to antagonize inflammatory reactions and later on impart in conversion of T- and B- cell population into regulatory subclasses.

Hostile environment resulting to hypoxia was found to decrease cytotoxic tumor infiltrating $\mathrm{T}$ cells and even when reactivated with $\mathrm{IL}-2$, their viability has decreased $^{[79]}$. These unfavorable condition for $\mathrm{T}$ cells has proposed requirement as limiting factor for CAR-T therapy in solid tumors where tumor size should be minimal, otherwise, any other therapies may fail. Despite of challenges in delivering and striving CAR-T cells in hypoxic environment, there has been pioneering study aimed to armor CAR-T cells with sensor to sense hypoxic environment ${ }^{[80]}$. The team added the oxygen-sensing domain of HIF gene to the intracellular domain of CAR construct. They found that CAR-T functionalities in killing cancer is not hindered in a low oxygen environment. Therefore, retaining immunologic function despite hostile environment.

D. Potentiating tumor targeting by fine-tuning ScFv affinity of CAR. We discussed previously the role of scFv (single chain variable fragment) domain of CAR in locating target cells. Antigen-recognition is vital in directing CAR-T cell effect against cancer. Other key factors that relates to the quality of $\mathrm{scFv}$ includes binding affinity which determines the efficiency of antigen recognition. In immunotherapy, $\mathrm{scFv}$ affinity is a dual edged functionality where too high interaction results in poor tissue penetration and distribution which may pose risk of side-effects due to potential concentration of immune effect in normal tissues. On the other hand, too low interaction may result in poor targeting of the desired antigen, hence causing low efficiency ${ }^{[81]}$.

CARs are derived from antibody $\mathrm{scFv}$ with unknown binding affinity or may have affinity that is altered after recombinant fusion with the intracellular domain. Study presented by Park et $a l^{[82]}$ demonstrated the use of enhanced anti-ICAM1 CAR-T cells targeting solid tumors in mouse. Increased molar affinity of ICAM-1 resulted in better distribution and eradicated preferentially tumor cells while keeping normal cells unharmed. In another study, anti-ErbB2 CAR harboring scFv with lower affinity has comparative anti-tumor activity against solid tumors with high-affinity CARs ${ }^{[83]}$. These two contradicting affinity features of CAR indicate the necessity of fine-tuning binding affinities based on complex factors such as cancer type, antigen density or may either be traced back to identifying suitable hybridoma or phage clones during antibody scFv development.

As discussed above, most of target antigens in solid cancer are also expressed in normal tissues. These studies on $\mathrm{scFv}$ fine-tuning are promising platform to teach 
CAR-T cells in discriminating normal from the cancer cells. It is important to note that fine-tuning scFV to harbor high or low binding affinity is an important avenue for improving CAR-T cells in providing safer and better anti-tumor effect. Various protein engineering approaches such as directed evolution ${ }^{[84]}$, domain exchange ${ }^{[85]}$, coupled with high-throughput analysis using phage display ${ }^{[88]}$ can assist in $\mathrm{scFv}$ fine tuning.

E. Neutralizing CAR-T toxicity. Currently, most of the targets in solid tumors are molecules found relatively in normal cells. CAR construct is designed to recognize specific antigen but CAR-T cells cannot distinguish between normal and cancer cells. Severity of this "on-target/off-tumor" toxicity range from cell linage depletion or aplasia with some reports describing severe toxicity leading to death. This problem is demonstrated by CD19 and carcinoembryonic antigen-directed CAR-T cells where normal cells are also recognized ${ }^{[87,88]}$. In some reports this type of toxicity have been addressed by fine-tuning $\mathrm{scFv}^{[89]}$ or identifying other targets that are more specific to cancer cells such as neoantigens $^{[90]}$.

The most prevalent side effect of CAR-T therapy is the early or onset immune activation known as cytokine release syndrome $(\mathrm{CRS})^{[91,27]}$. Even prior to encountering cancer antigen, CAR-T cells may start releasing cytotoxic molecules which orchestrate severe noncancer-specific inflammatory processes inside the body, targeting different organs and tissues. There are plenty of reasons why CRS occurs which include complexity of generating chimeric $\mathrm{T}$ cell functionalities and the generation of fine-tuned scFv as described above. Enhancing the anti-tumor activities of CAR-T cells is a "double-edged sword" that may either enhance tumor eradication or may escalate patients to life threatening situation ${ }^{[34]}$. Current CAR-T platforms developed to address cytotoxicity include developing switchable CAR (sCAR) equipped with switch-on mechanism to prevent early activation of CAR-T cells ${ }^{[92,93]}$. These sCARs utilize an anti-PNE (peptide neo-epitope) CAR with scFv domain that is specific to PNE epitope which is not found in human proteome. The sCAR is activated once it encounters a PNE-coupled antigen-specific scFv. Report on anti-CD19 sCAR-T cells showed a dose-dependent response without unwanted immune activation ${ }^{[92]}$.
Other modes of CAR-T variants being developed to bypass onset activation includes platforms that contain 'safety switch' such as iCAR and caspase-9-inducible CAR. The antigen-specific inhibitory chimeric antigen receptors or simply iCAR is another advancement in CAR-T therapy dampening $\mathrm{T}$ cell activation when $\mathrm{scFv}$ of iCAR recognizes normal cell antigen. This platform contains tumor-specific CAR that allows cancer-specific killing and an inhibitory iCAR that suppresses immune attack on normal tissue. Sadelain and coworkers ${ }^{[94]}$ demonstrated the use of PD-1 and CTLA-4 inhibitory domains to offset immune activation of cytotoxic CAR when CAR-T cells are trafficked in non-tumoral region. They showed that CD19-CAR/PSMA-iCAR T cells killed CD19+/PMSA- cells but not CD19+/PMSA+ cells. This iCAR is a promising approach to preventing CAR-T cells from eliciting immune attack when not needed. Same cytotoxicity management is employed in caspase-9-inducible CAR proposed by the team of Diaconu et $a l^{[95]}$. However, the CAR construct does not employ the use of immune checkpoint proteins but has an added caspase-9 intracellular domain activated by induced-dimerization of FK506-binding protein in the presence of pharmacological drug known as AP1903. This drug-induced dimerization to activate caspase-9 affords to manage toxicity by terminating the effects of CAR-T cells by apoptosis.

\subsection{Identifying weak spots in cancer cells:}

A. Targeting heterogeneous population of cancer cells in the tumor site. Cancer develops from accumulated mutations that initiates a malignant phenotype. As cancer cells continue to replicate, other clones harbor different genetic and epigenetic anomalies as they are exposed to different microenvironmental pressures ${ }^{[96]}$ such as deprivation of nutrients and oxygen as described above. Cancer cells in tumors are highly heterogeneous ${ }^{[97,98]}$ and CAR-T cells targeting only one specific antigen might not be sufficient enough to eradicate all targets, especially in metastatic cases where associated antigens are different from succeeding tumors. The big challenge in addressing heterogeneous cancer antigens in solid tumors is that most of the targets currently being employed for therapeutic evaluation are also expressed by normal cells ${ }^{[87]}$. However, some CAR-T cells would preferentially target tumor sites as most of these 
antigens are upregulated in tumor population however the greatest challenge is to execute $\mathrm{T}$ cell killing immediately on cancer cells before any harmful side effects have been made to normal cells and considering all other factors in directing CAR-T cells to the site of tumor (as described above).

In lieu of constructing CARs that express $\mathrm{scFv}$ against single targets, there have been reports that utilized dual or multiple targeting of tumor-associated antigens to bypass drawbacks in tumor heterogeneity ${ }^{[99,100]}$. Some innovative CAR designs employed the added inhibitory signals where one $\mathrm{scFv}$ recognize a tumor antigen while the other recognizes a protein expressed by normal tissue to make CAR-T therapy safer for use in cancer immunotherapy. Dual TAA-targeting has been also shown to enhance tumor eradication.

\section{B. Evading complexity of cancer genomic insta-}

bility. From the view point of mutations and epigenetic changes described recently, accumulated genomic changes may result in various genetic anomalies such as indels (insertion/deletion) or rearrangements leading to fused, altered or truncated proteins ${ }^{[101]}$. As clinical consequence, cancer cells might become less aggressive and patient respond easily to available treatment or they might become refractory or more aggressive leading to more serious conditions. Depending on kind of aberration, increased mutational load and high neoantigen frequency might be beneficial to some tumors such as high microsatellite instability (MSI ${ }^{\text {high}}$ ) in colorectal can$\operatorname{cer}^{[102,103]}$. However, some genomic aberrations result in poor prognosis such as high mutational burden in TP53 and RET in pancreatic cancer and APOBEC family of genes in multiple myeloma ${ }^{[104]}$.

In a bright note, these mutations and aberrant changes in chromosomal arrangements creates an altered protein product known as neoantigen. Cancer neoantigens are gene products with altered sequence or structure that may present immunogenic epitope for immunologic response ${ }^{[90]}$. Current approach in neoantigen treatment includes vaccine design which requires cloning and expression of the neoantigens which are induced to be immunogenic and later on triggers cancer killing ${ }^{[105]}$.

Neoantigens expressed on the surface of cancer cells could be potential targets and because they are only present in cancer cells, they offer a safer and more spe- cific tumor-associated targeting for CAR-T therapy. Roughly around 28 neoantigen clinical trials are being evaluated (based on Clinicaltrials.gov database search query) and one of them includes redirecting CAR-T cells to target neoantigens in solid tumors such as metastatic glioblastoma, lung cancer, ovarian, breast and gastrointestinal tumors ${ }^{[106]}$. However, the clinical efficacy and safety of this CAR-T platform is yet to be evaluated.

\section{Bypassing immune checkpoint inhibition. As} quality check process, $\mathrm{T}$ cells are regulated in two stages, central and peripheral tolerance. These $\mathrm{T}$ cell regulations are important to prevent auto-reactive $\mathrm{T}$ cells from attacking the normal tissues. Unlike developing $\mathrm{T}$ cells, CAR-T cells and their unmodified counterparts, are controlled at the periphery (peripheral tolerance) which is orchestrated by different immune checkpoint proteins. The PD1/PDL-1 axis is one of the very well-known immune checkpoint proteins associated with $\mathrm{T}$ cell suppression $^{[107]}$. The interaction of PD-1 (programmed cell death 1-receptor) on T cells to the ligand (PDL-1 or PDL-2) on normal tissues prevents autoimmunity ${ }^{[108]}$. However, this $\mathrm{T}$ cell suppression mechanism is also used by cancer where expression of these ligands (PDL1 and PDL2) are very high, correlating to poor prognosis in some cancer types $^{[109,110]}$. Clinical results on mune-checkpoint blockade using antibodies produced encouraging remission outcomes and increased patient survival in many types of solid cancers ${ }^{[111]}$. Some immune checkpoint blockade targets include PD-1, PDL-1, CTLA-4, TIM-3, LAG-3, and A2AR ${ }^{[112,108,113]}$, all are clinically evaluated for efficiency in eradicating cancer cells by antibody-mediated cancer killing.

CAR-T cells are not exempted from this immune checkpoint suppression as they also express these inhibitory molecules owing to their innate T cell nature. So far we discussed the importance of overcoming the presence of immune suppressing cytokines and other soluble factors that saturate the tumor stroma. In order to bypass this suppressing environment, additional inducible cytokine has to be equipped with CAR-T to potentiate immune attack. However, the presence of immune checkpoint proteins on cancer cells present another danger that might render CAR-T cells inefficient even equipped with various inflammatory cytokines.

In various CAR-T clinical trials, some patients were 
found to have increased PD-1 expression after few weeks of infusion ${ }^{[114]}$. In fact, some participant showed higher PD-1 expression in CAR-T cells compared to endogenous $\mathrm{T}$ cells ${ }^{[115]}$. These problems have led to combinatorial treatment of anti-PD1 or anti-PDL1 antibody following CAR-T treatment. Preclinical research and experimental animal models showed better tumor killing and enhanced CAR-T cell survival in the presence of PD-1 pathway blockade. Pioneering study by group of John et al. ${ }^{[116]}$ confirmed that anti-Her2 CAR-T cells can undergo $\mathrm{T}$ cell exhaustion after continuous stimulation with PDL-1+ Her- $2^{+}$tumor cells. In an in vitro set-up, they showed that treatment of anti-PD1 antibody in combination CAR-T cells enhanced $\mathrm{T}$ cell activation and proliferation. In their transgenic model, their anti-Her2 CAR-T cells strikingly produced better anti-tumor effect in the presence of anti-PD1 antibody.

Despite positive results of this combinatorial dosing, the separate cost and the independent side effects of each therapy could hinder access to this treatment. New platforms of CAR-T cells are now developed and currently under clinical trials to evaluate efficiency and safety of co-engineering CAR-T cells with antibody genes targeting these inhibitory molecules such as PD-1, CTLA-4 and PDL-1. These antibody-expressing CAR-T cells provide a "built-in" therapy that will no longer require co-administration of antibodies. Targets in solid tumors include MUC1 ${ }^{[117]}$, EGFR families ${ }^{[118]}$ and mesothelin ${ }^{[19]}$; however, their clinical efficiency are still being evaluated in clinical trials.

Other modes of engineering $\mathrm{T}$ cell in bypassing PD-1-mediated $\mathrm{T}$ cell suppression was demonstrated by chimerizing the PD-1 intracellular domain with the CD28 signaling region ${ }^{[120]}$. In this report, the scientists demonstrated increased $\mathrm{T}$ cell activation and proliferation accompanied with increased cytokine secretion and granzyme B release in their experimental model. This promising approach to turning inhibitory molecules to activate $\mathrm{T}$ cells by engineering the intracellular domain is a promising approach.

In some other reports, CAR-T cells can be co-engineered using CRISPR (clustered regularly interspaced short palindromic repeats)-Cas $9^{[121]}$ or RNAi (RNA interference) technology ${ }^{[122]}$ to harbor dominant-negative inhibitory receptor or could be knocked out, knocked down or removed from the loci to render the PD-1/PDL-1 axis inefficient to suppress $\mathrm{T}$ cell activity.

D. Circumventing down-regulation of antigen targets. As a well-established fundamental physiology by which cancer escape cell death or evade immune destruction is through downregulating tumor-associated antigens (TAAs) among all other things. Factors leading to reduced or loss of expression of these TAAs may attribute to genetic malfunctions already discussed above or may have been a physiological feedback or sporadic response which reduce the efficiency of any cancer therapy ${ }^{[123]}$. As exemplified by some clinical reports on breast cancer, endocrine therapy using tamoxifen was shown to induce loss of expression of target receptors such as ER (estrogen receptor) and progesterone receptor (PR) with clinical significance of resistance reaching to almost $20 \%^{[124]}$. It is now being recognized that the loss of presentation of internal TAAs or even neoantigens by MHC (major histocompatibility complex) class I hide cancer cells from being detected by immune cells, be it endogenous or the engineered counterpart ${ }^{[125-127]}$. Downregulation of latent membrane protein (LMP) 2, $\mathrm{LMP}^{[128,129]}$, transporter associated with antigen processing (TAP) 1 and TAP2 $2^{[130-132]}$ are some of the genes scientists are now looking in response to finding key features of developing immunotherapy-resistant cancer cells.

Similarly, in case of anti-CD19 CAR-T therapy targeting melanoma, scientists found that an isoform of CD19 with skipped exon 2 (CD19-e2) was upregulated leading to downregulation of the full-length CD19 target $^{[133]}$. This downregulation of the whole CD19 protein led to loss of cognate epitope necessary for CAR-T recognition. It is now being recognized that loss of antigen expression on tumor cells presents a very dramatic problem in CAR-T therapy and immunotherapy in general.

Current approach in CAR-T therapy using dual targeting CAR-T cells for two different TAAs might overcome this antigen downregulation by cancer cells. Preclinical and clinical studies using this approach produced a very promising result. Hedge et al. demonstrated that the combinatorial targeting of HER 2 and IL-13R $\alpha 2$ by CAR-T offset antigen escape and enhanced anti-tumor 
activity in vitro and in xenogeneic mouse model ${ }^{[134]}$.

\section{Molecular profiling of solid tu- mors}

Molecular changes that underlie tumorigenesis have been widely elucidated. In fact, a cancer cell from one patient or in a certain cancer group differs in molecular background ${ }^{[135-137]}$. This heterogeneity of cancer pathophysiology may provide answers why only a portion of the treated population respond to immunotherapy and why some tumors develop resistance to the treatment $^{[138,139]}$.

Molecular profiling has proven to be effective in providing adequate information to conclude prognosis and diagnosis of some diseases including providing clinical decisions for treatment and disease management ${ }^{[140,141]}$. Tumor profiling provides information on the molecular characteristics of cancer cells ${ }^{[142]}$. The elucidation of these 'characteristics' provides better understanding about the cancer cells and in translation may give clue to identifying appropriate therapy for patients. For example, $4^{\text {th }}$ generation caspase-9-inducible anti-CD19 CAR-T was found to rescue patient with chemo-refractory acute lymphoblastic leukemia carrying Bcr-Abl cytogenetic fusion and C275Y TP53 mutation $^{[143]}$ while some leukemia with different profiles might be refractory to the therapy. This finding correlates the importance of identifying biomarkers that might involve in sensitizing cancer cells for CAR-T therapy. Thus, tumor profiling allows tailor-fitting the specific CAR-T platforms needed by certain stratified tumor profile.

\section{Conclusion}

In this review, we outlined the major challenges of CAR-T therapy in solid tumors. The success of CAR-T therapy is affected by two factors: 1) the strategic efficiency of CAR-T cells; 2) and the susceptibility of cancer cells to immunotherapy. While it is important to note factors affecting CAR-T delivery and toxicity it is also very important to identify the extent of cancer heterogeneity and treatment sensitivity.

Recently, tumor profiling test has been ed by US FDA (Food and Drug Administration) for cancer diagnosis and prognosis ${ }^{[144,145]}$. This molecular profiling of tumors allows analyzing multiple genes that are associated with tumorigenesis that might aid in screening novel biomarkers for use in CAR-T therapy. The success of CAR-T treatment will be greatly influenced by the identification of these target antigens that are unique for each patient's solid tumor. This strategy will not be amenable to a mass-produced general CAR-T construct that can be recommended, for example, for all patients with lung cancer, breast cancer or pancreatic cancer. Considering the heterogeneity and variability of antigen expression of each patient's cancer, a personalized molecular-genetic approach will be needed for effective targeting of each patient's cancer, beyond the general organ-related categories in use currently.

\section{Conflict of Interest Statement}

The authors do not identify conflicts of interest in writing this review.

\section{References}

1. Huang, H., Jin, J., \& Li, X. (2014). Re: Factors affecting recurrence and progression of high grade non invasive bladder cancer treated by intravesical BCG. Pakistan Journal of Medical Sciences, 30 (6). doi:10.12669/pjms.306.6408.

2. Colombo, N., Lorusso, D., \& Scollo, P. (2017). Impact of Recurrence of Ovarian Cancer on Quality of Life and Outlook for the Future. International Journal of Gynecological Cancer, 27(6), 1134-1140. doi:10.1097/igc.0000000000001023.

3. Mayor, S. (2017). Risk of breast cancer recurrence remains for years after endocrine treatment ends, study finds. Bmj. doi:10.1136/bmj.j5167.

4. Hong, B., \& Zu, Y. (2013). Detecting Circulating Tumor Cells: Current Challenges and New Trends. Theranostics, 3(6), 377-394. doi:10.7150/thno.5195

5. Andree, K. C., Dalum, G. V., \& Terstappen, L. W. (2015). Challenges in circulating tumor cell detection by the CellSearch system. Molecular Oncology, 10(3), 395-407. doi:10.1016/j.molonc.2015.12.002

6. Al-Azri, M. H. (2016). Delay in Cancer Diagnosis: Causes and Possible Solutions. Oman Medical Journal, 31(5), 325-326. doi:10.5001/omj.2016.65

7. Walter, F. M., Rubin, G., Bankhead, C., Morris, H. C., Hall, N., Mills, K., Emery, J. (2015). Symptoms and other factors associated with time to diagnosis and stage of lung cancer: A prospective cohort study. British Journal of Cancer, 112 (S1). doi:10.1038/ bjc.2015.30.

8. Zahreddine, H., \& Borden, K. L. (2013). Mechanisms and insights into drug resistance in cancer. Frontiers in Pharmacology, 4. doi: 10.3389/fphar. 2013.00028.

9. Cornell, R. F., \& Kassim, A. A. (2016). Evolving paradigms in the treatment of relapsed/refractory multiple myeloma: Increased options and increased 
complexity. Bone Marrow Transplantation, 51(4), 479-491. doi:10.1038/bmt.2015.307

10. Schulze, A. B., \& Schmidt, L. H. (2017). PD-1 targeted Immunotherapy as first-line therapy for advanced non-small-cell lung cancer patients. Journal of Thoracic Disease, 9 (4). doi:10.21037/jtd.2017. 03. 118 .

11. Tessema, F. A., \& Darrow, J. J. (2017). A New Approach to Treat Childhood Leukemia: Novartis CAR-T Therapy. The Journal of Law, Medicine \& Ethics, 45 (4): 692-697. doi:10.1177/10731105177 50609.

12. Jain, M. D., Bachmeier, C. A., Phuoc, V. H., \& Chavez, J. C. (2018). Axicabtagene ciloleucel (KTE-C19), an anti-CD19 CAR T therapy for the treatment of relapsed/refractory aggressive B-cell non-Hodgkin's lymphoma. Therapeutics and Clinical Risk Management, Volume 14, 1007-1017. doi:10.2147/tcrm.s145039.

13. Rappl, G., Riet, T., Awerkiew, S., Schmidt, A., Hombach, A. A., Pfister, H., \& Abken, H. (2012). The CD3-Zeta Chimeric Antigen Receptor Overcomes TCR Hypo-Responsiveness of Human Terminal Late-Stage $\mathrm{T}$ Cells. PLoS ONE, 7 (1). doi:10.1371/journal.pone.0030713.

14. Munisvaradass, R., Kumar, S., Govindasamy, C., Alnumair, K., \& Mok, P. (2017). Human CD3 T-Cells with the Anti-ERBB2 Chimeric Antigen Receptor Exhibit Efficient Targeting and Induce Apoptosis in ERBB2 Overexpressing Breast Cancer Cells. International Journal of Molecular Sciences, 18 (9), 1797. doi:10.3390/ijms18091797.

15. Yi, Z., Prinzing, B. L., Cao, F., Gottschalk, S., \& Krenciute, G. (2018). Optimizing EphA2-CAR T Cells for the Adoptive Immunotherapy of Glioma. Molecular Therapy - Methods \& Clinical Development, 9, 70-80. doi:10.1016/j.omtm.2018.01.009

16. Gross, G., Waks, T., \& Eshhar, Z. (1989). Expression of immunoglobulin-T-cell receptor chimeric molecules as functional receptors with antibody-type specificity. Proceedings of the National Academy of Sciences, 86 (24), 10024-10028. doi:10.1073/pnas.86.24.10024.

17. Irving, B. A., \& Weiss, A. (1991). The cytoplasmic domain of the $\mathrm{T}$ cell receptor chain is sufficient to couple to receptor-associated signal transduction pathways. Cell, 64(5), 891-901. doi:10.1016/00928674 (91) 90314-o.

18. Brentjens, R. J., Nikhamin, Y., Matsushita, M., \& Sadelain, M. (2005). In Vitro and In Vivo Characterization of "Second-Generation" Co-Stimulatory Chimeric Antigen Receptors (CARs) Targeting the CD19 Antigen Present on B Cell Malignancies. Molecular Therapy, 11. doi:10.1016/j.ymthe.2005. 07.336

19. Tang, X., Sun, Y., Zhang, A., Hu, G., Cao, W., Wang, D., Chen, H. (2016). Third-generation CD28/4-1BB chimeric antigen receptor $\mathrm{T}$ cells for chemotherapy relapsed or refractory acute lymphoblastic leukaemia: A non-randomised, open-label phase I trial protocol. BMJ Open, 6 (12). doi: 10.1136/bmjopen-2016-013904.

20. Hombach, A. A., Heiders, J., Foppe, M., Chmielewski, M. \& Abken, H. (2012). OX40 costimulation by a chimeric antigen receptor abrogates CD28 and IL-2 induced IL-10 secretion by redirected CD4(+) T cells. Oncoimmunology, 1 (4): 458-466.

21. Guedan, S., Posey, A.D. Jr., Shaw, C., Wing, A., June, C.H. (2018). Enhancing CAR T cell persistence through ICOS and 4-1BB costimulation. JCI Insight, 3 (1): pii.96976. doi: 10.1172/jci.insight. 96976.

22. Song, D.G., Ye, Q., Poussin, M., Harms, G.M., Figini, M., Powell, D.J. Jr. (2012). CD27 costimulation augments the survival and antitumor activity of redirected human $\mathrm{T}$ cells in vivo. Blood, 119:696-706. doi: 10.1182/blood-2011-03-344275.

23. Chmielewski, M., \& Abken, H. (2017). CAR T Cells Releasing IL-18 Convert to T-Bet high FoxO1 low Effectors that Exhibit Augmented Activity against Advanced Solid Tumors. Cell Reports, 21 (11), 3205-3219. doi:10.1016/j.celrep.2017.11.063.

24. Zhang, L-N., Song, Y. and Liu, D. (2018). CD19 CAR-T cell therapy for relapsed/refractory acute lymphoblastic leukemia: factors affecting toxicities and long term efficacies. Journal of Hematology \& Oncology, 11: 41. doi: 10.1186/s13045-018-0593-5.

25. Ma, J.S., Kim, J.Y., Kazane, S.A., Choi, S.H., Cao, Y. (2016). Versatile strategy for controlling the specificity and activity of engineered $\mathrm{T}$ cells. Proc Natl Acad Sci USA, 113 (4): E450-8. doi: 10.1073/pnas.1524193113.

26. Mirzaei, H. R., Rodriguez, A., Shepphird, J., Brown, C. E., \& Badie, B. (2017). Chimeric Antigen Receptors T Cell Therapy in Solid Tumor: Challenges and Clinical Applications. Frontiers in Immunology, 8. doi:10.3389/fimmu.2017.01850.

27. D’Aloia, M.M., Zizzari, I.G., Sacchetti, B., Pierelli, L. \& Alimandi, M. (2018). CAR-T cells: the long and winding road to solid tumors. Cell Death Dis, 9 (3): 282. doi: 10.1038/s41419-018-0278-6.

28. Hu, M., Li, K., Maskey, N., Xu, Z., Yu, F., Peng, C., Yang, G. (2015). Overexpression of the chemokine receptor CXCR3 and its correlation with favorable prognosis in gastric cancer. Human Pathology, 46(12), 1872-1880. doi:10.1016/j.humpath.2015. 08.004 .

29. Postow, M. (2016). Faculty of 1000 evaluation for Non-redundant requirement for CXCR3 signalling during tumoricidal T-cell trafficking across tumour vascular checkpoints. F1000 - Post-publication Peer Review of the Biomedical Literature. doi:10.3410/ f.725587207.793524109.

30. Harlin, H., Meng, Y., Peterson, A. C., Zha, Y., Tretiakova, M., Slingluff, C., Gajewski, T. F. (2009). 
Chemokine Expression in Melanoma Metastases Associated with CD8 T-Cell Recruitment. Cancer Research, 69(7), 3077-3085. doi:10.1158/00085472.can-08-2281.

31. Craddock, J. A., Lu, A., Bear, A., Pule, M., Brenner, M. K., Rooney, C. M., \& Foster, A. E. (2010). Enhanced Tumor Trafficking of GD2 Chimeric Antigen Receptor T Cells by Expression of the Chemokine Receptor CCR2b. Journal of Immunotherapy, 33 (8), 780-788. doi:10.1097/cji.0b013e3181ee 6675.

32. Peng, W., Ye, Y., Rabinovich, B. A., Liu, C., Lou, Y., Zhang, M., Hwu, P. (2010). Transduction of Tumor-Specific T Cells with CXCR2 Chemokine Receptor Improves Migration to Tumor and Antitumor Immune Responses. Clinical Cancer Research, 16 (22), 5458-5468. doi:10.1158/1078-0432.ccr-100712.

33. Stasi, A. D., Angelis, B. D., Rooney, C. M., Zhang, L., Mahendravada, A., Foster, A. E., Savoldo, B. (2009). T lymphocytes coexpressing CCR4 and a chimeric antigen receptor targeting CD30 have improved homing and antitumor activity in a Hodgkin tumor model. Blood, 113 (25), 6392-6402. doi:10.1182/blood-2009-03-209650.

34. Newick, K., Obrien, S., Sun, J., Kapoor, V., Maceyko, S., Lo, A., Albelda, S. M. (2016). Augmentation of CAR T-cell Trafficking and Antitumor Efficacy by Blocking Protein Kinase A Localization. Cancer Immunology Research, 4 (6), 541-551. doi:10.1158/2326-6066.cir-15-0263.

35. ClinicalTrials.gov [Internet]. Bethesda (MD): National Library of Medicine (US). Identifier NCT03500991. HER2-specific CAR T Cell Locoregional Immunotherapy for HER2-positive Recurrent/Refractory Pediatric CNS Tumors. (n.d.). Cited 2018 June 22. Retrieved from https://clinicaltrials.gov/ct2/show/NCT03500991.

36. ClinicalTrials.gov [Internet]. Bethesda (MD): National Library of Medicine (US). Identifier NCT02850536. CAR-T Hepatic Artery Infusions or Pancreatic Venous Infusions for CEA-Expressing Liver Metastases or Pancreas Cancer. (n.d.). Cited 2018 June 22. Retrieved from https://clinicaltrials. gov/ct2/show/NCT02850536.

37. ClinicalTrials.gov [Internet]. Bethesda (MD): National Library of Medicine (US). Identifier NCT01818323. Phase I Trial: T4 Immunotherapy of Head and Neck Cancer. (n.d.). Cited 2018 June 22. Retrieved from https://clinicaltrials.gov/ct2/show/ NCT01818323.

38. Ajina, A., \& Maher, J. (2017). Prospects for combined use of oncolytic viruses and CAR T-cells. Journal for ImmunoTherapy of Cancer, 5.(1). doi:10.1186/s40425-017-0294-6.

39. Moon, E. K., Wang, L. S., Bekdache, K., Lynn, R. C., Lo, A., Thorne, S. H., \& Albelda, S. M. (2018). Intra-tumoral delivery of CXCL11 via a vaccinia virus, but not by modified T cells, enhances the efficacy of adoptive $\mathrm{T}$ cell therapy and vaccines. OncoImmunology, 7(3). doi:10.1080/2162402x.2017. 1395997.

40. Li, J., Omalley, M., Urban, J., Sampath, P., Guo, Z. S., Kalinski, P., Bartlett, D. L. (2011). Chemokine Expression From Oncolytic Vaccinia Virus Enhances Vaccine Therapies of Cancer. Molecular Therapy, 19 (4), 650-657. doi:10.1038/mt.2010.312.

41. Li, J., Omalley, M., Sampath, P., Kalinski, P., Bartlett, D. L., \& Thorne, S. H. (2012). Expression of CCL19 from Oncolytic Vaccinia Enhances Immunotherapeutic Potential while Maintaining Oncolytic Activity. Neoplasia, 14 (12). doi: 10.1593/neo. 121272.

42. Afanasiev, O. K., Nagase, K., Simonson, W., Vandeven, N., Blom, A., Koelle, D. M., Nghiem, P. (2013). Vascular E-Selectin Expression Correlates with CD8 Lymphocyte Infiltration and Improved Outcome in Merkel Cell Carcinoma. Journal of Investigative Dermatology, 133 (8), 2065-2073. doi:10.1038/jid.2013.36.

43. Ley, K., \& Kansas, G. S. (2004). Selectins in T-cell recruitment to non-lymphoid tissues and sites of inflammation. Nature Reviews Immunology, 4 (5), 325-336. doi:10.1038/nri1351.

44. Chae, Y. K., Choi, W. M., Bae, W. H., Anker, J., Davis, A. A., Agte, S., Giles, F. J. (2018). Overexpression of adhesion molecules and barrier molecules is associated with differential infiltration of immune cells in non-small cell lung cancer. Scientific Reports, 8 (1). doi:10.1038/s41598-018-194 54-3.

45. Anderson, K. G., Stromnes, I. M., \& Greenberg, P. D. (2017). Obstacles Posed by the Tumor Microenvironment to T cell Activity: A Case for Synergistic Therapies. Cancer Cell, 31 (3), 311-325. doi:10.101 6/j.ccell.2017.02.008.

46. Caruana, I., Savoldo, B., Hoyos, V., Weber, G., Liu, H., Kim, E. S., Dotti, G. (2015). Heparanase promotes tumor infiltration and antitumor activity of CAR-redirected T lymphocytes. Nature Medicine, 21 (5), 524-529. doi:10.1038/nm.3833.

47. Sengupta, S., Mohan, N., Chiocca, E. A., Sampath, P., \& Viapiano, M. (2016). Novel Car-T Cells Targeting The Extracellular Matrix Of Glioblastoma Induce Strong Anti-Tumor Immune Response. Neuro-Oncology, 18. Vi86-Vi87. doi: 10.1093/ neuonc/now212.362.

48. Huang, K., Hsiao, Y., Wu, T., Huang, A., Ai, L., \& Kuan, C. (2018). Targeting of vegfr2-expressing cells by chimeric antigen receptor (car) $t$ cells for solid tumour therapy. Immunotherapy and Cancer Vaccines. doi:10.1136/esmoopen-2018-eacr25.937.

49. Mckee, T. D., Grandi, P., Mok, W., Alexandrakis, G. Insin, N., Zimmer, J. P., Jain, R. K. (2006). Degradation of Fibrillar Collagen in a Human Melanoma Xenograft Improves the Efficacy of an Oncolytic 
Herpes Simplex Virus Vector. Cancer Research, 66(5), 2509-2513. doi:10.1158/0008-5472.can-052242.

50. Guedan, S., Rojas, J. J., Gros, A., Mercade, E., Cascallo, M., \& Alemany, R. (2010). Hyaluronidase Expression by an Oncolytic Adenovirus Enhances Its Intratumoral Spread and Suppresses Tumor Growth. Molecular Therapy, 18 (7), 1275-1283. doi: 10.1038/mt.2010.79.

51. Schäfer, S., Weibel, S., Donat, U., Zhang, Q., Aguilar, R. J., Chen, N. G., \& Szalay, A. A. (2012). Vaccinia virus-mediated intra-tumoral expression of matrix metalloproteinase 9 enhances oncolysis of PC-3 xenograft tumors. BMC Cancer, 12 (1). doi: 10.1186/1471-2407-12-366.

52. Hou, W., Chen, H., Rojas, J., Sampath, P., \& Thorne, S. H. (2014). Oncolytic vaccinia virus demonstrates antiangiogenic effects mediated by targeting of VEGF. International Journal of Cancer, 135 (5), 1238-1246. doi:10.1002/ijc.28747.

53. Adelfinger, M., Bessler, S., Frentzen, A., Cecil, A., Langbein-Laugwitz, J., Gentschev, I., \& Szalay, A. (2015). Preclinical Testing Oncolytic Vaccinia Virus Strain GLV-5b451 Expressing an Anti-VEGF Single-Chain Antibody for Canine Cancer Therapy. Viruses, 7 (7), 4075-4092. doi:10.3390/v7072811.

54. Currier, M. A., Eshun, F. K., Sholl, A., Chernoguz, A., Crawford, K., Divanovic, S., Cripe, T. P. (2013). VEGF Blockade Enables Oncolytic Cancer Virotherapy in Part by Modulating Intratumoral Myeloid Cells. Molecular Therapy, 21 (5), 1014-1023. doi:10.1038/mt.2013.39.

55. Hayes, A. J., Huang, W-Q., Yu, J., Li, L-Y. (2000). Expression and function of angiopoietin-1 in breast cancer. Br J Cancer, 83 (9): 1154-1160. doi: 10.1054/bjoc. 2000.1437

56. Kim, I., Moon, S., Park, S. K., Chae, S. W., \& Koh, G. Y. (2001). Angiopoietin-1 Reduces VEGF-Stimulated Leukocyte Adhesion to Endothelial Cells by Reducing ICAM-1, VCAM-1, and E-Selectin Expression. Circulation Research, 89 (6), 477-479. doi: 10.1161/hh1801.097034.

57. Whiteside, T. L. (2008). The tumor microenvironment and its role in promoting tumor growth. Oncogene, 27 (45), 5904-5912. doi:10.1038/onc.2008. 271.

58. Baum, J., \& Duffy, H. S. (2011). Fibroblasts and Myofibroblasts: What Are We Talking About? Journal of Cardiovascular Pharmacology, 57 (4), 376-379. doi:10.1097/fjc.0b013e3182116e39.

59. Shiga, K., Hara, M., Nagasaki, T., Sato, T., Takahashi, H., \& Takeyama, H. (2015). Cancer-Associated Fibroblasts: Their Characteristics and Their Roles in Tumor Growth. Cancers, 7 (4), 2443-2458. doi: 10.3390/cancers7040902.

60. Tao, L., Huang, G., Song, H., Chen, Y., \& Chen, L. (2017). Cancer associated fibroblasts: An essential role in the tumor microenvironment. Oncology
Letters, 14 (3), 2611-2620. doi:10.3892/ol.2017. 6497.

61. Räsänen, K., \& Vaheri, A. (2010). Activation of fibroblasts in cancer stroma. Experimental Cell Research, 316 (17), 2713-2722. doi: 10.1016/j.yexcr. 2010.04.032.

62. Franses, J. W., Baker, A. B., Chitalia, V. C., \& Edelman, E. R. (2011). Stromal Endothelial Cells Directly Influence Cancer Progression. Science Translational Medicine, 3 (66). doi: 10.1126/scitranslmed.3001542.

63. Maishi, N., \& Hida, K. (2017). Tumor endothelial cells accelerate tumor metastasis. Cancer Science, 108 (10), 1921-1926. doi:10.1111/cas.13336.

64. Ribeiro, A. and Okamoto, O. K. (2015). Combined effects of pericytes in the tumor microenvironment. Stem Cells Int, v2015. doi: 10.1155/2015/868475

65. Pircher, M., Schuberth, P., Gulati, P., Sulser, S., Weder, W., Curioni, A., Petrausch, U. (2015). FAP-specific re-directed $\mathrm{T}$ cells first in-man study in malignant pleural mesothelioma: Experience of the first patient treated. Journal for ImmunoTherapy of Cancer, 3. doi:10.1186/2051-1426-3-s2-p120.

66. Facciabene, A., Motz, G. T., \& Coukos, G. (2012). T-Regulatory Cells: Key Players in Tumor Immune Escape and Angiogenesis. Cancer Research, 72 (9), 2162-2171. doi:10.1158/0008-5472.can-11-3687.

67. Sarvaria, A., Madrigal, J. A., \& Saudemont, A. (2017). B cell regulation in cancer and anti-tumor immunity. Cellular \& Molecular Immunology, 14 (8), 662-674. doi:10.1038/cmi.2017.35.

68. Hasmim, M., Messai, Y., Ziani, L., Thiery, J., Bouhris, J., Noman, M. Z., \& Chouaib, S. (2015). Critical Role of Tumor Microenvironment in Shaping NK Cell Functions: Implication of Hypoxic Stress. Frontiers in Immunology, 6. doi:10.3389/ fimmu.2015.00482.

69. Mcdonnell, A. M., Lesterhuis, W. J., Khong, A., Nowak, A. K., Lake, R. A., Currie, A. J., \& Robinson, B. W. (2014). Tumor-infiltrating dendritic cells exhibit defective cross-presentation of tumor antigens, but is reversed by chemotherapy. European Journal of Immunology, 45 (1), 49-59. doi:10.1002/ eji.201444722.

70. Jackute, J., Zemaitis, M., Pranys, D., Sitkauskiene, B., Miliauskas, S., Vaitkiene, S., \& Sakalauskas, R. (2018). Distribution of M1 and M2 macrophages in tumor islets and stroma in relation to prognosis of non-small cell lung cancer. BMC Immunology, 19 (1). doi:10.1186/s12865-018-0241-4.

71. Medrek, C., Pontén, F., Jirström, K., \& Leandersson, K. (2012). The presence of tumor associated macrophages in tumor stroma as a prognostic marker for breast cancer patients. BMC Cancer, 12 (1). doi:10.1186/1471-2407-12-306.

72. Umansky, V., \& Sevko, A. (2012). Tumor Microenvironment and Myeloid-Derived Suppressor Cells. Cancer Microenvironment, 6 (2), 169-177. doi:10.1 
007/s12307-012-0126-7.

73. Gregory, A. D., \& Houghton, A. M. (2011). Tumor-Associated Neutrophils: New Targets for Cancer Therapy. Cancer Research, 71 (7), 2411-2416. doi:10.1158/0008-5472.can-10-2583.

74. Vona-Davis, L. and Gibson, L. (2013). Adipocytes as a critical component of the tumor microenvironment. Leuk Res, 37 (5): 483-848. doi: 10.1016/j. leukres.2013.01.007.

75. Bussard, K. M., Mutkus, L., Stumpf, K., Marini, F. C. (2016). Tumor-associated stromal cells as key contributors to the tumor microenvironment. Breast Cancer Res, 18 (84). doi: 10.1186/s13058-016-07 40-2.

76. Li, H., Fan, X. and Houghton, J. (2007). Tumor microenvironment: the role of the tumor stroma in cancer. J Cell Biochem, 101: 805-815. doi: $10.1002 / \mathrm{jcb} .21159$.

77. Westendorf, A., Skibbe, K., Adamczyk, A., Buer, J., Geffers, R., Hansen, W., Jendrossek, V. (2017). Hypoxia Enhances Immunosuppression by Inhibiting CD4 Effector T Cell Function and Promoting Treg Activity. Cellular Physiology and Biochemistry, 41 (4), 1271-1284. doi:10.1159/000464429.

78. Semenza, G. L. (2006). Regulation of physiological responses to continuous and intermittent hypoxia by hypoxia-inducible factor 1 . Experimental Physiology, 91 (5), 803-806. doi:10.1113/expphysiol.2006. 033498.

79. Silly, R. V., Derouazi, M., Dietrich, P. Y., \& Walker, P. R. (2015). Hypoxia promotes IL-10 secretion by reactivated CTLs while limiting their expansion. Annals of Oncology, 26 (Suppl 8), Viii14-Viii14. doi:10.1093/annonc/mdv514.35.

80. Juillerat, A., Marechal, A., Filhol, J. M., Valogne, Y., Valton, J., Duclert, A., Poirot, L. (2017). An oxygen sensitive self-decision making engineered CAR T-cell. Scientific Reports, 7(1). doi:10.1038/srep 39833.

81. Lucas, A. T., Price, L. S., Schorzman, A. N., Storrie, M., Piscitelli, J. A., Razo, J., \& Zamboni, W. C. (2018). Factors Affecting the Pharmacology of Antibody-Drug Conjugates. Antibodies, 7(10). doi:10. 3390/antib7010010.

82. Park, S., Shevlin, E., Vedvyas, Y., Zaman, M., Park, S., Min, I. M., \& Jin, M. M. (2017). Micromolar affinity CAR T cells to ICAM-1 achieves rapid tumor elimination while avoiding systemic toxicity. Cancer Research, 77, 3750-3750. doi:10.1158/1538 -7445.am2017-3750.

83. Liu, X., Jiang, S., Fang, C., Yang, S., Olalere, D., Pequignot, E. C., Zhao, Y. (2015). Affinity-Tuned ErbB2 or EGFR Chimeric Antigen Receptor T Cells Exhibit an Increased Therapeutic Index against Tumors in Mice. Cancer Research, 75 (17), 3596-3607. doi:10.1158/0008-5472.can-15-0159.

84. Li, D., Wang, L., Maziuk, B. F., Yao, X., Wolozin, B., \& Cho, Y. K. (2018). Directed evolution of a picomolar-affinity, high-specificity antibody targeting phosphorylated tau. Journal of Biological Chemistry, 293 (31), 12081-12094. doi:10.1074/jbc. ra118.003557.

85. Chiu, M. L., \& Gilliland, G. L. (2016). Engineering antibody therapeutics. Current Opinion in Structural Biology, 38, 163-173. doi:10.1016/j.sbi.2016.07. 012.

86. Li, K., Zettlitz, K. A., Lipianskaya, J., Zhou, Y., Marks, J. D., Mallick, P., Wu, A. M. (2015). A fully human $\mathrm{scFv}$ phage display library for rapid antibody fragment reformatting. Protein Engineering Design and Selection, 28 (10), 307-316. doi:10.1093/protein/gzv024.

87. Davila, M. and Brentjens, R. (2016). CD19-targeted CAR $T$ cells as novel cancer immunotherapy for relapsed or refractory B-cell acute lymphoblastic leukemia. Clin Adv Hematol Oncol, 14 (10): 802-808.

88. Tasian, S. K., \& Gardner, R. A. (2015). CD19-redirected chimeric antigen receptor-modified $\mathrm{T}$ cells: A promising immunotherapy for children and adults with B-cell acute lymphoblastic leukemia (ALL). Therapeutic Advances in Hematology, 6 (5), 228-241. doi:10.1177/20406207 15588916.

89. Watanabe, N., Bajgain, P., Sukumaran, S., Ansari, S., Heslop, H. E., Rooney, C. M., Vera, J. F. (2016). Fine-tuning the CAR spacer improves T-cell potency. OncoImmunology, 5 (12). doi:10.1080/2162402 x.2016.1253656.

90. Lu, Y., \& Robbins, P. F. (2016). Cancer immunotherapy targeting neoantigens. Seminars in Immunology, 28 (1), 22-27. doi:10.1016/j.smim.2015.11. 002.

91. Bonifant, C. L., Jackson, H. J., Brentjens, R. J., \& Curran, K. J. (2016). Toxicity and management in CAR T-cell therapy. Molecular Therapy - Oncolytics, 3, 16011. doi:10.1038/mto.2016.11.

92. Rodgers, D. T., Mazagova, M., Hampton, E. N., Cao, Y., Ramadoss, N. S., Hardy, I. R., Young, T. S. (2016). Switch-mediated activation and retargeting of CAR-T cells for B-cell malignancies. Proceedings of the National Academy of Sciences, 113 (4). doi: 10.1073/pnas.1524155113.

93. Cao, Y., Rodgers, D. T., Du, J., Ahmad, I., Hampton, E. N., Ma, J. S., Young, T. S. (2016). Design of Switchable Chimeric Antigen Receptor $\mathrm{T}$ Cells Targeting Breast Cancer. Angewandte Chemie, 128(26), 7646-7650. doi:10.1002/ange.201601902

94. Fedorov, V. D., Themeli, M., \& Sadelain, M. (2013). PD-1- and CTLA-4-Based Inhibitory Chimeric Antigen Receptors (iCARs) Divert Off-Target Immunotherapy Responses. Science Translational Medicine, 5(215). doi:10.1126/scitranslmed.3006597.

95. Diaconu, I., Ballard, B., Zhang, M., Chen, Y., West, J., Dotti, G., \& Savoldo, B. (2017). Inducible Caspase-9 Selectively Modulates the Toxicities of 
CD19-Specific Chimeric Antigen Receptor-Modified T Cells. Molecular Therapy, 25 (3), 580-592. doi:10.1016/j.ymthe.2017.01.011.

96. Sadikovic, B., Al-Romaih, K., Squire, J., \& Zielenska, M. (2008). Cause and Consequences of Genetic and Epigenetic Alterations in Human Cancer. Current Genomics, 9.(6), 394-408. doi:10.2174/138 920208785699580.

97. Dagogo-Jack, I., \& Shaw, A. T. (2017). Tumour heterogeneity and resistance to cancer therapies. Nature Reviews Clinical Oncology, 15 (2), 81-94. doi:10.1038/nrclinonc.2017.166.

98. Meacham, C. E., \& Morrison, S. J. (2013). Tumour heterogeneity and cancer cell plasticity. Nature, 501(7467), 328-337. doi:10.1038/nature12624.

99. Genßler, S., Burger, M. C., Zhang, C., Oelsner, S., Mildenberger, I., Wagner, M., Wels, W. S. (2015). Dual targeting of glioblastoma with chimeric antigen receptor-engineered natural killer cells overcomes heterogeneity of target antigen expression and enhances antitumor activity and survival. OncoImmunology, 5(4). doi:10.1080/2162402x.2015. 1119354.

100. Thomas, S., Baldan, V., Kokalaki, E., Righi, M., Sillibourne, J., Cordoba, S., Pule, M. (2017). A Dual Targeting Car-T Cell Approach For The Treatment Of B Cell Malignancies. Hematological Oncology, 35, 261-261. doi:10.1002/hon.2438_129.

101. Negrini, S., Gorgoulis, V. G., \& Halazonetis, T. D. (2010). Genomic instability — an evolving hallmark of cancer. Nature Reviews Molecular Cell Biology, 11 (3), 220-228. doi:10.1038/nrm2858.

102. Saridaki, Z. (2014). Prognostic and predictive significance of MSI in stages II/III colon cancer. World Journal of Gastroenterology, 20 (22), 6809. doi:10.3748/wjg.v20.i22.6809.

103. Gatalica, Z., Vranic, S., Xiu, J., Swensen, J., \& Reddy, S. (2016). High microsatellite instability (MSI-H) colorectal carcinoma: A brief review of predictive biomarkers in the era of personalized medicine. Familial Cancer, 15 (3), 405-412. doi:10.1007/s10689-016-9884-6.

104. Walker, B. A., Wardell, C. P., Murison, A., Boyle, E. M., Begum, D. B., Dahir, N. M., Morgan, G. J. (2015). APOBEC family mutational signatures are associated with poor prognosis translocations in multiple myeloma. Nature Communications, 6 (1). doi:10.1038/ncomms7997.

105. Walters, J. N., Ferraro, B., Duperret, E. K., Kraynyak, K. A., Chu, J., Saint-Fleur, A., Weiner, D. B. (2017). A Novel DNA Vaccine Platform Enhances Neo-antigen-like $\mathrm{T}$ Cell Responses against WT1 to Break Tolerance and Induce Anti-tumor Immunity. Molecular Therapy, 25 (4), 976-988. doi:10.1016/j.ymthe.2017.01.022.

106. ClinicalTrials.gov [Internet]. Bethesda (MD): National Library of Medicine (US). Identifier NCT03412877. Administration of Autologous
T-Cells Genetically Engineered to Express T-Cell Receptors Reactive Against Mutated Neoantigens in People with Metastatic Cancer. (n.d.). Cited 2018 June 22. Retrieved from https://clinicaltrials.gov/ ct2/show/NCT03412877.

107. Mcclanahan, F., Riches, J. C., Miller, S., Day, W. P., Kotsiou, E., Neuberg, D., Gribben, J. G. (2015). Mechanisms of PD-L1/PD-1-mediated CD8 T-cell dysfunction in the context of aging-related immune defects in the E -TCL1 CLL mouse model. Blood, 126 (2), 212-221. doi:10.1182/blood-2015-02-62 6754.

108. Zamani, M. R., Aslani, S., Salmaninejad, A., Javan, M. R., \& Rezaei, N. (2016). PD-1/PD-L and autoimmunity: A growing relationship. Cellular Immunology, 310, 27-41. doi:10.1016/j.cellimm.2016.09. 009.

109. Xiang, X., Yu, P., Long, D., Liao, X., Zhang, S., You, X. Li, L. (2018). Prognostic value of PD-L1 expression in patients with primary solid tumors. Oncotarget, 9(4). doi:10.18632/oncotarget.23580.

110. Zhu, J., Wen, H., Bi, R., Wu, Y., \& Wu, X. (2017). Prognostic value of programmed death-ligand 1 (PD-L1) expression in ovarian clear cell carcinoma. Journal of Gynecologic Oncology, 28 (6). doi:10.3802/jgo.2017.28.e77.

111. Balar, A. V., \& Weber, J. S. (2017). PD-1 and PD-L1 antibodies in cancer: Current status and future directions. Cancer Immunology, Immunotherapy, 66 (5), 551-564. doi:10.1007/s00262-0171954-6.

112. Korman, A. J., Peggs, K. S., \& Allison, J. P. (2006). Checkpoint Blockade in Cancer Immunotherapy. Advances in Immunology Cancer Immunotherapy, 297-339. doi: 10.1016/s0065-2776(06)90008-x.

113. Pardoll, D. M. (2012). The blockade of immune checkpoints in cancer immunotherapy. Nature Reviews Cancer, 12 (4), 252-264. doi:10.1038/nrc 3239.

114. Kochenderfer, J. N., Somerville, R. P., Lu, T., Yang, J. C., Sherry, R. M., Feldman, S. A., Rosenberg, S. A. (2017). Long-Duration Complete Remissions of Diffuse Large B Cell Lymphoma after Anti-CD19 Chimeric Antigen Receptor T Cell Therapy. Molecular Therapy, 25 (10), 2245-2253. doi:10.1016/j. ymthe.2017.07.004.

115. Brudno, J. N., Somerville, R. P., Shi, V., Rose, J. J., Halverson, D. C., Fowler, D. H., .Kochenderfer, J. N. (2016). Allogeneic T Cells That Express an Anti-CD19 Chimeric Antigen Receptor Induce Remissions of B-Cell Malignancies That Progress After Allogeneic Hematopoietic Stem-Cell Transplantation Without Causing Graft-Versus-Host Disease. Journal of Clinical Oncology, 34(10), 1112-1121. doi:10.1200/jco.2015.64.5929.

116. John, L. B., Devaud, C., Duong, C. P., Yong, C. S., Beavis, P. A., Haynes, N. M., . Darcy, P. K. (2013). Anti-PD-1 Antibody Therapy Potently Enhances the 
Eradication of Established Tumors By Gene-Modified T Cells. Clinical Cancer Research, 19(20), 5636-5646. doi:10.1158/1078-0432.ccr-13 $-0458$.

117. ClinicalTrials.gov [Internet]. Bethesda (MD): National Library of Medicine (US). Identifier NCT03179007. CTLA-4 and PD-1 Antibodies Expressing MUC1-CAR-T Cells for MUC1 Positive Advanced Solid Tumor. (n.d.). Retrieved from https://clinicaltrials.gov/ct2/show/NCT03179007.

118. ClinicalTrials.gov [Internet]. Bethesda (MD): National Library of Medicine (US). Identifier NCT03182816. CTLA-4 and PD-1 Antibodies Expressing EGFR-CAR-T Cells for EGFR Positive Advanced Solid Tumor. (n.d.). Cited 2018 June 22. Retrieved from https://clinicaltrials.gov/ct2/show/ NCT03182816.

119. ClinicalTrials.gov [Internet]. Bethesda (MD): National Library of Medicine (US). Identifier NCT03030001. PD-1 Antibody Expressing CAR T Cells for Mesothelin Positive Advanced Malignancies. (n.d.). Retrieved September 05, 2018, from https://clinicaltrials.gov/ct2/show/NCT03030001.

120. Liu, X., Ranganathan, R., Jiang, S., Fang, C., Sun, J., Kim, S., Moon, E. K. (2016). A Chimeric Switch-Receptor Targeting PD1 Augments the Efficacy of Second-Generation CAR T Cells in Advanced Solid Tumors. Cancer Research, 76 (6), 1578-1590. doi:10.1158/0008-5472.can-15-2524.

121. Rupp, L. J., Schumann, K., Roybal, K. T., Gate, R. E., Ye, C. J., Lim, W. A., \& Marson, A. (2017). CRISPR/Cas9-mediated PD-1 disruption enhances anti-tumor efficacy of human chimeric antigen receptor T cells. Scientific Reports, 7 (1). doi: 10.1038/s41598-017-00462-8.

122. Ligtenberg, M. A., Coaña, Y. P., Shmushkovich, T., Yoshimoto, Y., Truxova, I., Yang, Y., Kiessling, R. (2018). Self-Delivering RNAi Targeting PD-1 Improves Tumor-Specific $\mathrm{T}$ Cell Functionality for Adoptive Cell Therapy of Malignant Melanoma. Molecular Therapy, 26 (6), 1482-1493. doi:10.1016 /j.ymthe.2018.04.015.

123. Olson, B. M., \& Mcneel, D. G. (2012). Antigen loss and tumor-mediated immunosuppression facilitate tumor recurrence. Expert Review of Vaccines, 11(11), 1315-1317. doi:10.1586/erv.12.107.

124. Giuliano, M., Schiff, R., Osborne, C. K., \& Trivedi, M. V. (2011). Biological mechanisms and clinical implications of endocrine resistance in breast cancer. The Breast, 20. doi:10.1016/s0960-9776(11)702 93-4.

125. Garrido, F., Ruiz-Cabello, F., Cabrera, T., Pérez-Villar, J. J., López-Botet, M., Duggan-Keen, M., \& Stern, P. L. (1997). Implications for immunosurveillance of altered HLA class I phenotypes in human tumours. Immunology Today, 18 (2), 89-95. doi:10.1016/s0167-5699(96)10075-x.

126. Seliger, B., Cabrera, T., Garrido, F., \& Ferrone, S.
(2002). HLA class I antigen abnormalities and immune escape by malignant cells. Seminars in Cancer Biology, 12 (1), 3-13. doi:10.1006/scbi.2001. 0404.

127. Atkins, D., Breuckmann, A., Schmahl, G. E., Binner, P., Ferrone, S., Krummenauer, F., Seliger, B. (2004). MHC class I antigen processing pathway defects, ras mutations and disease stage in colorectal carcinoma. International Journal of Cancer, 109(2), 265-273. doi:10.1002/ijc.11681

128. Ritter, C., Fan, K., Paschen, A., Hardrup, S. R., Ferrone, S., Nghiem, P., Becker, J. C. (2017). Epigenetic priming restores the HLA class-I antigen processing machinery expression in Merkel cell carcinoma. Scientific Reports, 7 (1). doi:10.1038/ s41598-017-02608-0.

129. Koerner, J., Brunner, T., \& Groettrup, M. (2017). Inhibition and deficiency of the immunoproteasome subunit LMP7 suppress the development and progression of colorectal carcinoma in mice. Oncotarget, 8 (31). doi: 10.18632/oncotarget.15141.

130. Glavinas, H., Krajcsi, P., Cserepes, J., \& Sarkadi, B. (2004). The Role of ABC Transporters in Drug Resistance, Metabolism and Toxicity. Current Drug Delivery, 1 (1), 27-42. doi:10.2174/156720104348 0036.

131. Henle, A. M., Nassar, A., Puglisi-Knutson, D., Youssef, B., \& Knutson, K. L. (2017). Downregulation of TAP1 and TAP2 in early stage breast cancer. Plos One, 12 (11). doi: 10.1371/journal.pone.018 7323.

132. Ling, A., Löfgren-Burström, A., Larsson, P., Li, X., Wikberg, M. L., Öberg, Å, Palmqvist, R. (2017). TAP1 down-regulation elicits immune escape and poor prognosis in colorectal cancer. OncoImmunology, 6 (11). doi:10.1080/2162402x.2017.135 6143.

133. Fischer, J., Paret, C., Malki, K. E., Alt, F., Wingerter, A., Neu, M. A., Faber, J. (2017). CD19 Isoforms Enabling Resistance to CART-19 Immunotherapy Are Expressed in B-ALL Patients at Initial Diagnosis. Journal of Immunotherapy, 40 (5), 187-195. doi:10.1097/cji.0000000000000169.

134. Hegde, M., Mukherjee, M., Grada, Z., Pignata, A., Landi, D., Navai, S. A., Ahmed, N. (2016). Tandem CAR T cells targeting HER2 and IL13R $\alpha 2$ mitigate tumor antigen escape. Journal of Clinical Investigation, 126 (8), 3036-3052. doi:10.1172/jci83416.

135. Gong, Y., Liu, Y., Ji, P., Hu, X., \& Shao, Z. (2017). Impact of molecular subtypes on metastatic breast cancer patients: A SEER population-based study. Scientific Reports, 7 (1). doi:10.1038/srep45411.

136. Palma, M. D., \& Hanahan, D. (2012). The biology of personalized cancer medicine: Facing individual complexities underlying hallmark capabilities. Molecular Oncology, 6 (2), 111-127. doi:10.1016/j. molonc.2012.01.011

137. Zhou, J., Yan, Y., Guo, L., Ou, H., Tang, L. (2014). 
Distinct outcomes in patients with different molecular subtypes of inflammatory breast cancer. Saudi Med J, 35 (11): 1324-1330.

138. Enck, P., Klosterhalfen, S., Weimer, K., Horing, B., \& Zipfel, S. (2011). The placebo response in clinical trials: More questions than answers. Philosophical Transactions of the Royal Society B: Biological Sciences, 366 (1572), 1889-1895. doi:10.1098/ rstb.2010.0384.

139. Garnett, S. A., Martin, M., Jerusalem, G., Petruzelka, L., Torres, R., Bondarenko, I. N., Leo, A. D. (2013). Comparing duration of response and duration of clinical benefit between fulvestrant treatment groups in the CONFIRM trial: Application of new methodology. Breast Cancer Research and Treatment, 138 (1), 149-155. doi:10.1007/s10549012-2395-8.

140. Cross, D., \& Burmester, J. K. (2004). The Promise of Molecular Profiling for Cancer Identification and Treatment. Clinical Medicine \& Research, 2 (3), 147-150. doi:10.3121/cmr.2.3.147.

141. Ioannidis, J. P. (2007). Is Molecular Profiling Ready for Use in Clinical Decision Making? The Oncologist, 12 (3), 301-311. doi:10.1634/theoncologist.12-3-301.

142. Greco, F. A., Spigel, D. R., Yardley, D. A., Erlander, M. G., Ma, X., \& Hainsworth, J. D. (2010). Molecular Profiling in Unknown Primary Cancer: Accuracy of Tissue of Origin Prediction. The Oncologist, 15(5), 500-506. doi:10.1634/theoncologist.200903281.

143. Niu, T., Chang, L-J., Yang, J., Liu, Y., Liu, T. (2015). Rescue of a terminally ill patient with chemo-refractory acute lymphoblastic leukemia carrying Bcr/Abl and TP53 mutations based on a 4th generation CD19 chimeric antigen receptor-engineered T (CAR-T) therapy. Blood, 126 (23): 5431.

144. Cheng, D. T., Mitchell, T. N., Zehir, A., Shah, R. H., Benayed, R., Syed, A., Berger, M. F. (2015). Memorial Sloan Kettering-Integrated Mutation Profiling of Actionable Cancer Targets (MSK-IMPACT). The Journal of Molecular Diagnostics, 17 (3), 251-264. doi:10.1016/j.jmoldx.2014.12.006.

145. Zehir, A., Benayed, R., Shah, R., Syed, A., Berger, M. (2017). Mutational landscape of metastatic cancer revealed from prospective clinical sequencing of 10,000 patients. Nat Med, 23 (6): 703-713. doi: 10.1038/nm.4333. 